\title{
The Effect of Richard Wagner's Music and Beliefs on Hitler's Ideology
}

Carolyn S. Ticker

Cedarville University, cticker@cedarville.edu

Follow this and additional works at: https://digitalcommons.cedarville.edu/musicalofferings

Part of the European History Commons, Fine Arts Commons, Musicology Commons, and the Music Performance Commons

DigitalCommons@Cedarville provides a publication platform for fully open access journals, which means that all articles are available on the Internet to all users immediately upon publication. However, the opinions and sentiments expressed by the authors of articles published in our journals do not necessarily indicate the endorsement or reflect the views of DigitalCommons@Cedarville, the Centennial Library, or Cedarville University and its employees. The authors are solely responsible for the content of their work. Please address questions to dc@cedarville.edu.

\section{Recommended Citation}

Ticker, Carolyn S. (2016) "The Effect of Richard Wagner's Music and Beliefs on Hitler's Ideology," Musical Offerings: Vol. 7 : No. 2 , Article 1.

DOI: 10.15385/jmo.2016.7.2.1

Available at: https://digitalcommons.cedarville.edu/musicalofferings/vol7/iss2/1 


\title{
The Effect of Richard Wagner's Music and Beliefs on Hitler's Ideology
}

\section{Document Type}

Article

\begin{abstract}
The Holocaust will always be remembered as one of the most horrific and evil events in all of history. One question that has been so pervasive in regards to this historical event is the question of why. Why exactly did Hitler massacre the Jewish people? Why did he come to the conclusion that the Jews were somehow lesser than him, and that it was okay to kill them? What and who were his influences and how did they help form Hitler's opinions leading up to the Holocaust? Although more than one situation or person influenced Hitler, I believe that one man in particular really helped contribute to Hitler's ideas, especially about the Jewish people. This man is the famous musician Richard Wagner. While musicologists admit that Wagner was a musical genius, one aspect of his career that is hard to ignore is his strong antisemitism. In addition to speaking about his hatred for the Jews, he also wrote about it in his music, making it hard to glance over. Hitler had been close to the Wagner family, and had an obsessive, cult-like infatuation with Wagner's music beginning in his childhood. This infatuation with Wagner's music and his closeness to his later family helped facilitate and solidify his negative views about the Jewish people. In this paper I will explore the antisemitism that is within Wagner's music and writing, and then I will discuss how Wagner's antisemitism helped inform, influence, and shape Hitler's ideas, indirectly assisting in the propagation of the Holocaust.
\end{abstract}

\section{Keywords}

Wagner, Hitler, Holocaust, music, antisemitism, ideology, influence

\section{Creative Commons License}

\section{(c) (†) $\ominus$}

This work is licensed under a Creative Commons Attribution-Noncommercial-No Derivative Works 4.0 License. 


\title{
The Effect of Richard Wagner's Music and Beliefs on Hitler's Political Ideology
}

\author{
Carolyn S. Ticker \\ Cedarville University
}

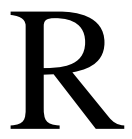

egarded as one of the worst periods in history, the Holocaust brought death and destruction to millions of innocent Jewish

citizens. Since that time, it has not been easy for humanity as a whole to come to terms with what happened or even to understand what drove Hitler to commit such atrocious acts. While it is difficult to know for certain what caused the Holocaust, those whom Hitler was influenced by provide important clues. One man in particular, Richard Wagner, a German composer, lived before Hitler's time but held very strong antiSemitic political opinions. Wagner had an especially large following, which included the young Adolf Hitler, a lover of his music and an avid supporter of him. Wagner's music was often played on special Nazi occasions during Hitler's political regime. ${ }^{1}$ Hitler was also closely connected to Wagner's family throughout his time in power. Although Wagner cannot be solely held responsible for Hitler's actions during WWII, both Wagner's political musings and his music display his strong desire for a pure German race, free from any other ethnicity. Hitler's strong support of Wagner's music and his association with some of Wagner's family members reflect his commitment to the ideology of Wagner, which in turn affected his own opinion; thus, Wagner is attributed an indirect, but costly, connection with the Holocaust.

Richard Wagner's fame is rather paradoxical. On one hand, he is considered the German Romantic musical genius, renowned by many all over the world. On the other hand, however, he is extremely controversial; while musicians cannot deny his sheer talent, reconciling his racism while still appreciating his music is difficult to do. Terry Teachout, in his article entitled "Hitler's Accompanist," points out that

\footnotetext{
${ }^{1}$ Terry Teachout, "Hitler's Accompanist," Commentary, January 1, 2008, https://www.commentarymagazine.com/articles/hitlers-accompanist/.
}

Musical Offerings, vol. 7, no. 2, pp. 55-66. ISSN 2330-8206 (print); ISSN 2167-3799 (online);

(C) 2016, Carolyn Ticker, licensed under CC BY-NC-ND (http://creativecommons.org/licenses/by-nc-nd/3.0/) 
Wagner's now-tainted reputation is not exactly unfair, considering his political views. ${ }^{2}$ It is a dilemma that people have not yet been able to overcome. For instance, consider the Israeli state, which after World War II allowed many Jewish immigrants to come if they sought refuge. ${ }^{3}$ As they welcomed more and more immigrants to Palestine, anti-German feelings became stronger and stronger. Beginning in the 1930s, Israel, understandably, instituted a ban on all performances of Wagner's music as a result of his strong anti-Semitic views. ${ }^{4}$

In addition to being a composer, Wagner was also at the forefront of the political arena. In 1850 he wrote his most famous article entitled "Das Judentum in der Musik," or "Judaism in Music." He originally wrote under a pseudonym but later decided to take full credit, publishing it under his own name. His prejudice toward the Jewish people can be seen clearly through his writing. In the article, he says that "the Jew-who, as everyone knows, has a God all to himself-in ordinary life strikes us primarily by his outward appearance, which, no matter to what European nationality we belong, has something disagreeably foreign to that nationality: instinctively we wish to have nothing in common with a man who looks like that." ${ }^{5}$ His opinions are clearly derogatory; belittling the Jew based on looks alone, he claims that "every non-Jew is viscerally repulsed by Jews," although he supports that position with little evidence. $^{6}$

Wagner argues that the Jewish person "speaks the language of the nation in whose midst he dwells from generation to generation, but he speaks it always as an alien." "7 According to James Loeffler, Wagner was intent on describing the Jews as "Other," and so "with no genuine or organic connection to German or any other European language, the Jews could

\footnotetext{
2 Teachout, "Hitler's Accompanist."

${ }^{3}$ Na'ama Sheffi, "Cultural Manipulation: Richard Wagner and Richard Strauss in Israel in the 1950s," Journal of Contemporary History 34, no. 4 (1999): 622.

${ }^{4}$ James Loeffler, 'Richard Wagner's 'Jewish Music': Antisemitism and Aesthetics in Modern Jewish Culture," Jewish Social Studies (Indiana University) 15, no. 2 (2009): 3.

${ }^{5}$ Richard Wagner, "Judaism in Music," in Richard Wagner's Prose Works, vol. 3, The Theatre, trans. William Ashton Ellis (London: Kegan Paul, Trench, Trübner, 1894), 82-83.

${ }^{6}$ Michael Haas, Forbidden Music: The Jewish Composers Banned by the Nazis (New Haven, CT: Yale University Press, 2013), 32.

${ }^{7}$ Wagner, "Judaism in Music," 84.
} 
not by the standards of German Romanticism possess a culture." 8 Wagner also refers to the Jews' speech as outlandish and unpleasant, and he questions how they would, then, be able to produce music of artistic beauty through singing. ${ }^{9}$ There was, in his opinion, no way that the Jewish composer could fit the German Romantic view of greatness. If Wagner was so quick to say that Jews had no place in music, is it not also reasonable that Wagner most likely felt this way about German culture at large: that the Jewish people did not belong?

Although it can be easy to fault Wagner for his feelings of German superiority, he was not the first to express pride in his nationality. During the Romantic Era, the spread of nationalism gave root to the perception that one's nation is better than other nations. Nationalism served as a catalyst for national pride and political movements. People displayed this in many different ways, including music. Following Germany's part in this nationalistic fervor in the nineteenth century, "Germanness" became an ideal in music, and many people "privileged a German style of music over French and Italian models." 10

Wagner's opinions did not keep only within the limits of his political writings; he portrayed his anti-Semitic opinions very clearly in most of his music. To understand this, a look must be given to some of his operas. One of his most famous operas, Die Meistersinger (originally written in 1845), is frequently touted as his most anti-Semitic opera. It centers on two main characters, named Beckmesser and Walther von Stolzing. According to Barry Millington, author of the article entitled "Nuremberg Trial: Is There Anti-Semitism in 'Die Meistersinger?,"' Beckmesser is said to be the quintessential picture of anti-Semitism:

The characterisation of Beckmesser draws directly on a common fund of nineteenth-century anti-Semitic stereotypes, specifically on the description of Jews in Wagner's pamphlet Das Judentum in der Musik (Jewishness in Music) (1850). According to that conventional image, the Jew shuffles and blinks, is scheming and argumentative, and is not to be trusted. So Beckmesser slinks up the alley behind the night

\footnotetext{
${ }^{8}$ Loeffler, "Richard Wagner's 'Jewish Music,"” 6.

${ }^{9}$ Wagner, "Judaism in Music," 85-86.

${ }^{10}$ Nicholas Vazsonyi, "Marketing German Identity: Richard Wagner's 'Enterprise,"' German Studies Review (Johns Hopkins University) 28, no. 2 (2005): 332 .
} 
watchman in Act II, and limps and stumbles about the stage in Act III, blinking with embarrassment when Eva turns away from his ingratiating bow at the song contest. ${ }^{11}$

For an audience member today, Beckmesser's qualities would not automatically stand out, but people watching the opera before 1945 would have understood Beckmesser's characterization and what it implied about his ethnicity. ${ }^{12}$ Millington states that Beckmesser is represented as the outsider from the very beginning of the play and "is made painfully and cruelly aware of his Otherness in the course of the opera." In the serenade in act 2 of Die Meistersinger, for instance, Beckmesser shows himself to be "utterly incapable of matching the text to appropriate musical phrases." Because the serenade sounds very similar to the traditional bel-canto aria that Wagner was trying to eradicate, the scene may suggest that Beckmesser has an old, reactionary, and outdated style. Furthermore, when Beckmesser sings, he wrongly accents certain syllables and sings with disjointed rhythms, largely parodying the Jewish cantorial style. Whereas the protagonist Walther von Stolzing can sing beautiful melodies, Beckmesser can only manage to release a garbled sound. ${ }^{13}$ This musical characterization of Beckmesser provides a good example of the differences between the Jewish caricature and the German one. It is difficult to deny that Beckmesser "was invested with traits conforming to the anti-Semitic stereotypes," and his encapsulation of the characteristics embodied in Wagner's "Das Judentum" "is a startling fact that almost of itself provides proof of Wagner's anti-Semitic intent in Die Meistersinger." 14

Wagner's writings deal consistently with the concept of degeneration, the idea that Germany's heritage is "threatened by a swarm of dark and physiologically inferior Jews from the East." 15 In his book Richard Wagner and the Anti-Semitic Imagination, Marc Weiner analyzes physiological differences, according to Wagner, between the eyes, the

\footnotetext{
${ }^{11}$ Barry Millington, "Nuremberg Trial: Is There Anti-Semitism in 'Die Meistersinger?," Cambridge Opera Journal 3, no. 3 (1991): 249.

12 Patrick Lo, “"The Most German of all German Operas': An Analysis of Richard Wagner's Die Meistersinger and its Influence on Hitler's Nazi Ideology," International Journal of the Humanities 7, no. 9 (2009): 86. ${ }^{13}$ Millington, "Nuremberg Trial," 247-251.

${ }^{14}$ Ibid., 255.

${ }^{15}$ Marc. A Weiner, Richard Wagner and the Anti-Semitic Imagination (Lincoln, University of Nebraska Press, 1995), 307.
} 
voices, the smells, and the feet of the Jew and of the German. This concept is especially evident in Die Meistersinger when Jewish Beckmesser and Eva, "the purest of German maidens," almost unite in marriage. Their unification, according to Wagner, would signify the end of the pure German race. ${ }^{16}$ Likewise, this threat of potential contamination by an inferior race is a continually recurring theme in Wagner's other operas. Wagner seemed to be consumed with this "fantasy about pure origin," which revolved around the desire for a pure, unified German state. ${ }^{17}$ There is even some speculation that Wagner himself might have been Jewish, as he did not know who his true father was. ${ }^{18}$ Perhaps fear of his uncertain ethnicity may have spurred this desire for a pure race, but to this day the question remains unanswered.

A second opera of Wagner's that is known for its anti-Semitism is Parsifal. The character Klingsor provides the perfect example of a person excluded. Klingsor, who wishes to become a Knight of the Holy Grail, is excluded because his community perceives him and his strong desires as not being "chaste." Rejected, he decided to castrate himself so that he would be accepted. This, however, served only to further alienate him from his community, since they looked upon his actions as unnatural and disgusting. Because of this rejection, Klingsor ends up becoming the evil magician, the main antagonist of the opera. ${ }^{19}$ Klingsor's treatment on a musical level is similar to Beckmesser's in Die Miestersinger. For example, in measures 623-657 of act 1, the introduction of Klingsor's motive stands in stark contrast to the prior motives of the "Dresden Amen" and "Holy Grail." The use of chromaticism and dotted rhythms make his motive sound much more unstable throughout. Yan postulates that while this stark musical difference may simply highlight the difference in the opera between what is evil and what is holy, it can also represent the threat of "blood-contamination" by Klingsor. ${ }^{20}$ Klingsor's failed attempt to fix himself aligns with Wagner's view in "Das Judentum" that "there are certain characteristics pertaining to the Jews that are ineradicable." Yan comments, "The forced attempt to deny such an original nature of the Jew, foresees Wagner, would only lead to further

\footnotetext{
${ }^{16}$ Weiner, Anti-Semitic Imagination, 307.

${ }^{17}$ James Treadwell, Interpreting Wagner (New Haven, CT: Yale University Press, 2003), 105.

${ }^{18}$ Weiner, Anti-Semitic Imagination, 3.

${ }^{19}$ Hector K. T. Yan, "The Jewish Question Revisited: Anti-Semitism and 'Race' in Wagner's 'Parsifal,'" International Review of the Aesthetics and Sociology of Music 43, no. 2 (2012): 349.

${ }^{20}$ Yan, "The Jewish Question Revisited," 350.
} 
heartlessness." 21 While Wagner's operas are not identical, the musical portrayals of Beckmesser and Klingsor in these operas equally showcase Wagner's intended disparity between the Jew and the pure-blooded German.

Even those living during Wagner's time recognized his anti-Semitic feelings. For example, Richard Wagner's son, Siegfried, wrote to the Jewish rabbi of Bayreuth in 1924, hoping to gain favor for a Wagnerian music festival. The rabbi's negative reply shows that the Wagner family was clearly linked to an anti-Semitic nationalist movement:

There is a widespread view that your house is a stronghold of this völkisch movement. . . . Members of your family wear swastikas. Your family ... is said to support the völkisch parties with substantial funding. Is it any surprise that decent men and women of the Jewish faith here and abroad exercise caution regarding things Wagnerian, and are not willing to offer contributions that they fear may indirectly go to benefit the völkisch movement? ${ }^{22}$

As a result of this anti-Semitic link, the rabbi wanted no part of Siegfried's attempt to gain his support and no part in funding the festival.

It is clear within Wagner's compositions and writings that he desired a pure German race, but how did his anti-Semitic stance come to infatuate Hitler? To what extent did Wagner's ideas of race influence Hitler's actions of massacre? Hitler's connection to Wagner is rather evident. He loved and spoke highly of Wagner's operas, in which he felt an identification with the story lines, the music, and the composer himself. Hitler also had close personal ties to the family of Wagner. In essence, Hitler felt connected to Wagner and his music, and this fueled his love for the ideas of Wagner.

The young Adolf loved Wagner's music and also knew it very well. Hitler was introduced to his music at a relatively young age when he saw a 1906 production of Rienzi in Linz. From that point on, Hitler made every effort to attend many of Wagner's operas, attempting to soak in as

${ }^{21}$ Yan, "The Jewish Question Revisited," 349.

${ }^{22}$ Brigitte Hamann, Winifred Wagner: The Life at the Heart of Hitler's

Bayreuth (Orlando: Harcourt, 2005), 94. 
much of Wagner as he could. According to Joachim Köhler, Hitler claimed in 1925 to have seen all of Wagner's operas many times and have spent his last penny just to be able to listen to his music. Supposedly, Hitler saw Tristan und Isolde at least thirty or forty times and knew much of the opera by heart, able to sing and hum it at a whim. ${ }^{23}$ Winifred Wagner, daughter-in-law to Richard Wagner, stated that Hitler was "addicted" to his music. This obsession for Wagner's music is made apparent by his possession of many of the original opera scores. ${ }^{24}$ For example, according to Michael Kater in his book The Twisted Muse: Musicians and Their Music in the Third Reich, Hitler kept the piano score of Tristan und Isolde in his knapsack while a soldier in World War I. ${ }^{25}$ While possessing someone's work would not necessarily suggest allegiance to or support of that composer, Hitler's close keeping of the piece while in the war suggests that he felt comforted by Wagner's music. In Hitler's case, his unusual ownership of Wagner's original scores is evidence of his love for his music.

The words of Hitler himself also provide evidence which is difficult to ignore, effectively debunking any attempts of freeing Wagner from this association with the Third Reich. Hitler commended Wagner on numerous occasions, whether in conversation with people he knew, in several of his letters, or even in his book, Mein Kampf. He wrote in Mein Kampf this memoir about his love for Wagner's music:

A precocious revolutionary in politics I was no less a precocious revolutionary in art. At that time the provincial capital of Upper Austria had a theatre which, relatively speaking, was not bad. Almost everything was played there. When I was twelve years old I saw William Tell performed. That was my first experience of the theatre. Some months later I attended a performance of Lohengrin, the first opera I had ever heard. I was fascinated at once. My youthful enthusiasm for the Bayreuth Master knew no limits. Again and again I was drawn to hear his operas; and to-day I consider it a great piece of luck that these modest productions in the little

\footnotetext{
${ }^{23}$ Joachim Köhler, Wagner's Hitler: The Prophet and His Disciple (Cambridge: Polity, 2000), 54-55.

${ }^{24}$ Ibid., 13-14.

${ }^{25}$ Michael H. Kater, The Twisted Muse: Musicians and Their Music in the Third Reich (New York: Oxford University Press, 1997), 36.
} 
provincial city prepared the way and made it possible for me to appreciate the better productions later on. ${ }^{26}$

Hitler himself admits his infatuation with Wagner, saying that from the very first time he saw a production of one of Wagner's operas he was enraptured by it. This primary source supports the truthfulness of secondary accounts written by men such as Köhler and Kater.

In addition to Hitler's words in Mein Kampf, he also spoke highly of Wagner to others. Take, for example, his words to Rauschnigg as recorded in the book Hitler Speaks: "I recognize in Wagner my only predecessor. .. . I regard him as a supreme prophetic figure." ${ }^{27}$ This quote provides the most compelling and accurate evidence for the connection between these two men, more so than any other piece of evidence. It gives one the full sense of Hitler's awe of him. This was not a mere liking of another man's music; this was a full-fledged idolatry of another man. Hitler admitted to the world that Wagner served as his inspiration. He, apparently, told one of his architects that Wagner's music was the cause that inspired him to unite the German nation. ${ }^{28}$ "Wagner was his kindred spirit, his forerunner, his John the Baptist; Wagner portrayed what he, Hitler, a greater than Wagner, was to translate into reality." ${ }^{29}$ Wagner encapsulated all that Hitler believed in - the superiority of the German race - and it was this superiority that Hitler sought to protect and implement. $^{30}$

Although Hitler was impressionable, there must have been something else, other than the music, that drew Hitler to Wagner. Richard Wagner's works are regarded highly and are often considered among musicians to be the epitome of German Romantic music. But, a composer's work alone is rarely enough to elicit such strong devotion. Hans Rudolf Vaget points out a remark in which Hitler said, referring to a performance of

\footnotetext{
${ }^{26}$ Adolf Hitler, Mein Kampf: The Official 1939 Edition, trans. James Murphy, (Warwickshire, UK: Coda, 2011), 20.

${ }^{27}$ Robert L. Jacobs, “Wagner's Influence on Hitler," Music \& Letters (Oxford University) 22, no. 1 (1941): 81.

${ }^{28}$ Ronald Taylor, introduction to Wagner's Hitler: The Prophet and His Disciple, by Joachim Köhler, trans. Ronald Taylor (Cambridge: Polity, 2000), 3 .

${ }^{29}$ Jacobs, "Wagner's Influence on Hitler," 82.

${ }^{30}$ DeLora J. Neuschwander, "Music in the Third Reich," Musical Offerings (Cedarville University) 3, no. 2 (2012): 99.
} 
Rienzi which he saw in Weimar, "in that hour, it all began." ${ }^{31}$ More than likely, this was not referring to his love for Wagner's music, since he had seen many of Wagner's operas from a young age. In all likelihood, his quotation refers to the moment when he first felt the desire to restore German greatness, just as Rienzi tried to do for the Roman state. ${ }^{32}$

Both Hitler and Wagner shared similarities, especially in regard to Hitler's career as a politician. Wagner's participation in the 1848 revolution and his subsequent exile were uncannily similar to Hitler's own failed attempt at a coup, which "landed him in jail and forced him to witness the proscription of his National Socialist Party. . . . Indeed destruction itself, both conceptually and in practice, forms a bond between the two men." 33 This similarity between them must have strengthened Hitler's devotion to Wagner, as he more than likely saw in Wagner a role model whom he could emulate in his attempt to unite the German nation.

One of the ways in which Hitler showed his dedication to Wagner was through his financial commitment to the Bayreuth festival. The festival became officially instituted by Hitler in 1933, and he wanted to insure that it would continue to run annually. In addition to all of this, in 1938 he "financed the promotion of Wagner research in the town." 34 His attendance at the festival every year was treated as a national spectacle by the media and helped to put his own regime on public display. ${ }^{35}$

The love that Hitler had for Wagner did not just stop at his music, however. He was said to have had connections to the Wagner family, specifically to Richard's daughter-in-law, Winifred. Hitler first became acquainted with the Wagner family in 1923 when he came to Bayreuth. He was invited to breakfast by Winifred and her husband Siegfried, and he cordially accepted, also stopping to visit Wagner's grave. The visit is said to be the start of his budding friendship with Winifred. She was noticeably impressed by him: "He was modest, had good manners, and showed how deeply impressed [by Wagner] he was." 36 Although the

\footnotetext{
${ }^{31}$ Hans Rudolf Vaget, "Wagnerian Self-Fashioning: The Case of Adolf Hitler," New German Critique (Duke University) 34, no. 2 (2007): 100. ${ }^{32}$ Ibid.

${ }^{33}$ Taylor, introduction to Wagner's Hitler, 3.

${ }^{34}$ Erik Levi, Music in the Third Reich, (New York: St. Martin's Press, 1994), 35.

${ }^{35}$ Kater, Twisted Muse, 38.

${ }^{36}$ Hamann, Winifred Wagner, 59.
} 
Wagner family had not yet aligned themselves with Hitler's party, they did shortly thereafter when he rose to greater power. For instance, Winifred wrote these words in an open letter:

Everyone in Bayreuth knows that we enjoy friendly relations with Adolf Hitler. ... His personality has made a profound and moving impression on us, as it does on everybody who meets him. ... I admit frankly that we too are under the spell of this personality, and that we too, who were behind him in happier times, will now stand by him in his hour of need..$^{37}$

Winifred and Siegfried Wagner's devotion can be seen even more clearly in a letter written by Winifred in 1924 while Hitler was imprisoned, which reads, "No other man has ever played such a role in our lives as Hitler does - he must be a powerful personality - for how else can you explain such passionate reverence and dedication? Either he will rescue us, or they will allow him, delicate as he is, to perish miserably in his prison-house! But if they do - then woe to Germany!!!" 38 In addition to the words of support, Winifred even wrote him letters and sent him gifts while he was imprisoned as a source of encouragement. ${ }^{39}$

It is difficult to ignore both Richard Wagner's anti-Semitic views and the many ties between him and Adolf Hitler. Through his political writings and his operas, it is made clear that Wagner desired a pure German race and thought less of the Jews. Furthermore, several memoirs show that Hitler did not only love Wagner's music, but he also had a strong connection with Wagner's immediate family while in political office. These things arguably helped form many of his opinions and political ideologies. With this in mind, the association between Wagner and the Holocaust is difficult to deny. Even though Hitler had many influences, the evidence is clear: Wagner's ideas helped inform and shape Hitler's views, thereby playing a role, albeit a small one, in the Holocaust.

\footnotetext{
${ }^{37}$ Hamann, Winifred Wagner, 67-68.

${ }^{38}$ Ibid., 74.

${ }^{39}$ Ibid., 72.
} 


\section{Bibliography}

Applegate, Celia, and Pamela Potter, eds. Music and German National Identity. Chicago: University of Chicago Press, 2002.

Brustein, William I. Roots of Hate: Anti-Semitism in Europe before the Holocaust. New York: Cambridge University Press, 2003.

Evans, Joan. "Stravinsky's Music in Hitler's Germany." Journal of the American Musicological Society 56, no. 3 (2003): 525-594. doi:10.1525/jams.2003.56.3.525.

Gilbert, Shirli. Music in the Holocaust: Confronting Life in the Nazi Ghettos and Camps. Oxford: Oxford University Press, 2005.

Haas, Michael. Forbidden Music: The Jewish Composers Banned by the Nazis. New Haven, CT: Yale University Press, 2013.

Hamann, Brigitte. Winifred Wagner: A Life at the Heart of Hitler's Bayreuth. Translated by Alan Bance. Orlando: Harcourt, 2005. Hitler, Adolf. Mein Kampf: The Official 1939 Edition. Translated by James Murphy. Warwickshire, UK: Coda, 2011.

Jacobs, Robert L. "Wagner's Influence on Hitler." Music \& Letters (Oxford University) 22, no. 1 (1941): 81-83. doi:10.1093/ml/XXII.1.81.

Jacobson, Joshua R. "Music of the Jewish People." Choral Journal 55, no. 2 (2014): 67-69. EBSCOhost (97524391).

Kater, Michael H. Composers of the Nazi Era: Eight Portraits. New York: Oxford University Press, 2000.

. The Twisted Muse: Musicians and Their Music in the Third Reich. New York: Oxford University Press, 1997.

Köhler, Joachim. Wagner's Hitler: The Prophet and His Disciple. Translated by Ronald Taylor. Cambridge: Polity, 2000.

Levi, Erik. Music in the Third Reich. New York: St. Martin's Press, 1994. Lo, Patrick. "'The Most German of All German Operas': An Analysis of Richard Wagner's Die Meistersinger and its Influence on Hitler's Nazi Ideology." International Journal of the Humanities 7, no. 9 (2009): 71-102. EBSCOhost (47937529).

Loeffler, James. "Richard Wagner's 'Jewish Music': Antisemitism and Aesthetics in Modern Jewish Culture." Jewish Social Studies (Indiana University) 15, no. 2 (2009): 2-36. http://www.jstor.org/stable/10.2979/jss.2009.15.2.2.

Ludwig, Mark. "Silenced Voices: Music in the Third Reich." Religion and the Arts (Boston College) 4, no. 1 (2000): 96-112. doi:10.1163/15685290152126449.

Meyer, Michael. The Politics of Music in the Third Reich. New York: Peter Lang, 1991. 
Millington, Barry. "Nuremberg Trial: Is There Anti-Semitism in 'Die Meistersinger?"' Cambridge Opera Journal 3, no. 3 (1991): 247-260. http://www.jstor.org/stable/823618.

Nemtsov, Jascha, Beate Schröder-Nauenburg, and Dean Bell. "Music in the Inferno of the Nazi Terror: Jewish Composers in the 'Third Reich."' Shofar: An Interdisciplinary Journal of Jewish Studies (Perdue University) 18, no. 4 (2000): 79-100. doi:10.1353/sho.2000.0147.

Neuschwander, DeLora J. "Music in the Third Reich." Musical Offerings (Cedarville University) 3, no. 2 (2012): 93-108. doi:10.15385/jmo.2012.3.2.3.

Potter, Pamela M. "Dismantling a Dystopia: On the Historiography of Music in the Third Reich." Central European History 40, no. 4 (2007): 623-651. doi:10.1017/S0008938907001069.

Sheffi, Na'ama. "Cultural Manipulation: Richard Wagner and Richard Strauss in Israel in the 1950s." Journal of Contemporary History 34, no. 4 (1999): 619-639. http://www.jstor.org/stable/261255.

Teachout, Terry. "Hitler's Accompanist." Commentary. January 1, 2008. https://www.commentarymagazine.com/articles/hitlersaccompanist/.

Thacker, Toby. Music after Hitler, 1945-1955. Burlington, VT: Ashgate, 2007.

Treadwell, James. Interpreting Wagner. New Haven, CT: Yale University Press, 2003.

Vaget, Hans Rudolf. "Wagnerian Self-Fashioning: The Case of Adolf Hitler." New German Critique (Duke University) 34, no. 2 (2007): 95-114. doi:10.1215/0094033X-2007-004.

Vazsonyi, Nicholas. "Marketing German Identity: Richard Wagner's 'Enterprise." German Studies Review (Johns Hopkins University) 28, no. 2 (2005): 327-346. http://www.jstor.org/stable/30038152.

Wagner, Richard. “Judaism in Music.” In Richard Wagner's Prose Works. Vol. 3, The Theatre, 79-100. Translated by William Ashton Ellis. London: Kegan Paul, Trench, Trübner, 1894.

Weiner, Marc A. Richard Wagner and the Anti-Semitic Imagination. Lincoln: University of Nebraska Press, 1995.

Yan, Hektor K. T. "The Jewish Question Revisited: Anti-Semitism and 'Race' in Wagner's 'Parsifal."' International Review of the Aesthetics and Sociology of Music 43, no. 2 (2012): 343-363. http://www.jstor.org/stable/23342826. 